\author{
$8^{\text {th }}$ International Conference on \\ Architecture Research and Design (AR+DC) \\ November 1-2, 2016
}

\title{
The creative hawker center for small - family - business in traditional food of Surabaya
}

\author{
Gunawan Tanuwidjaja ${ }^{\mathrm{a}^{*}}$, Daniel $^{\mathrm{b}}$, Ishak Tedjo ${ }^{\mathrm{b}}$, Ritzky Karina Brahmana ${ }^{\mathrm{c}}$ \\ ${ }^{a}$ Architecture Program Study, Petra Christian University, Jl. Siwalankerto 121-131, Surabaya, 60231, Indonesia \\ ${ }^{b}$ Students of Architecture Program Study, Petra Christian University, Jl. Siwalankerto 121-131, Surabaya, 60231, Indonesia \\ ${ }^{c}$ Marketing Program, Petra Christian University, Jl. Siwalankerto 121-131, Surabaya, 60231, Indonesia \\ *Corresponding author. Tel.: +62-031-298 3382 \\ E-mail address: gunte@petra.ac.id
}

\begin{abstract}
The Traditional Food Seller were mostly managed by the family, so they could be categorized as Family Businesses (FB). Furthermore, The FB in traditional food needed integrated business development strategy (related to marketing, business information system as well as architectural design). It was found during the research supported by UBCHEA in Surabaya. One of the strategies needed was to create the legal family food hawker center place quality. The strategy was in line with the Surabaya Municipality Government, The Cooperative and SME's Business (Dinas Koperasi dan UMKM). A mini hawker center (consisting of 5 hawkers) was proposed in the roadside of the neighborhood collector. Additional to the center, a culinary park was provided onsite for catering the social interactions of Indonesian. The center was designed with creativity, but with low-cost local material such as brick, wood and bamboo. The design was also equipped with clean water, sanitations as well as food storages. All these would create positive branding and ensure sustainability of the hawker center.
\end{abstract}

Keywords: family business; traditional food; creative Mini-Hawker Center

\section{Introduction}

The growth of street vendors (Pedagang Kaki Lima or PKL) Surabaya occurred rapidly at $2 \%$ per year. It was driven by the needs of the community for more economical goods. And they could be provided by about 50,000 street vendors Surabaya. So, empowerment and assistance were needed to improve the welfare of society and PKL.

On the other hand, unregulated layout and arrangement of food PKL in the streets or riverbanks often created a negative image of the PKL. Meanwhile, visitors comfort aspect and hygienic food supply were also affected because of poor layout and arrangement. Therefore, PKL should be designed with due regard to the factors cleanliness, neatness, and the convenience of visitors, to be able to compete with the surrounding sellers.

Surabaya Government has already designated several food center for catering the traditional food hawker in Surabaya. Several existing food center such as Taman Bungkul, Menanggal, Karah, Semolowaru, etc were already created but found less vibrant because of limited marketing and business development strategy as well as architectural design. Therefore, an integrated marketing and business development solutions were needed.

The Food Hawker (that included as Small and Medium Enterprises) also faced difficulty in increasing business scale, productivity and competing internationally because of competitiveness issue such as limited human resources, limited marketing strategy, etc. (Utami \& Lantu, 2014). Therefore, an integrated multidisciplinary approach were needed. 
The effort would be created to produce an integrated solution for the traditional food hawker consisting of:

- marketing and business development strategy

- architectural and interior design strategy of food stall

\section{Research theory and methods}

The Eastern Java Food was found very interested (Nurlaela, Ismawati, \& Sumarno, 2008). The food varieties were found including main meals, snacks and traditional drinks. Three regional food were explored and four food components were identified, such as: staple food, side food (fish or poultry or meat or vegetables), snacks and drinks. Some traditional foods were known and consumed in Surabaya. From Surabaya, Semanggi (clover salad), Lontong Balap (compressed rice and noodle), Lontong Kupang (compressed rice and mussel), Rujak Cingur (cow mouth salad) were popular. Secondly, Meanwhile, Nasi Krawu, Pudak and Jubung were widely consumed in Gresik. Tahu Campur (mixed beancurd), Sego Boranan (mixed rice) were popular in Lamongan. Sego pecel (Rice and salad) were consumed in Madiun, Nganjuk, and Ponorogo area. So it could be concluded that the Eastern Java food were related to available food ingredients, the cultural pattern of Islamic - Javanese - Maduranese as well as acculturation with other culture such as Chinese, Middle Eastern and India.

(Widodo, 2011) also documented authentic foods of Surabaya. Snacks named of Bikang, Onde-onde, Nogosari, Kucur, Getas, Klepon, Lopis, Klanting,and Gethuk. Many authentic foods were discussed, such as: Rawon, Soto, Tahu Campur, Lonthong Balap dan Kupang Lonthong, Therefore, the traditional food of Surabaya were important to document because of the cultural value of the food.

Related to Food Service, some literature was reviewed. (Voon, 2012) found relatively service-driven restaurant industry was very important from 409 samples of restaurant, (145 fine dining restaurants, 147 fast food restaurants and 117 food courts). The key determinants for restaurant service quality were such as:

- The physical environment or restaurant's design was found to increase the competitiveness such as: the attractiveness of the physical facilities, availability of parking space, cleanliness, temperature, music, colour scheme of the place, smell/scent, labels/signage and design/layout.

- Human service was found very important also comprising 3 sub-aspects such as: assurance, reliability and empathy. The assurance aspect comprised of criteria, such as: well-dressed and appear neat, wear sanitary gloves and hair net, friendly, polite, knowledgeable, can be trusted. Secondly, the reliability aspect comprised aspect of the service: promised service as promised, helpful, made the customer feeling confident, charged accurately, onschedule service. Thirdly, the empathy aspect comprised of individual attention, convenient operating hours, complete packaged food, sauces /spices always available.

- Food quality comprised of clean, healthy, fresh and has a variety of the food.

- Price comprised of competitive price, good value for money, willing to give special prices.

- Youth satisfaction comprised of overall satisfaction, quality of service experience, meet expectation.

- Lastly, the Youth loyalty comprised of repurchase intention and recommend to others.

Related to architectural design, (Kotler, 1973) found the consumer behaviour was affected by the physical environment, such as visual (color, lighting, proximity and number of visual elements); aural (music type, sound level); tactile (cleanliness); and olfactory (scent). (Ariffin, Bibon, \& Abdullah, 2012) also found that Restaurant's Atmospheric Elements affected the youth customer behaviour. The dimensions of colour, design, lighting, and restaurant layout were measured from 300 youth customers. 


\section{Methodology:}

The paper was produced from the Capturing the Family Business Resilience in Traditional Food Sector in Surabaya. The project was conducted from April 2015 to May 2016 by team of Petra Christian University (PCU). The Project was supported by UBCHEA (The United Board for Christian Higher Education in Asia, www.unitedboards.org). One of the purposes of the project was to conduct community outreach program for smallscale family business in traditional food sector.

Literature Review was conducted based in books and journals of traditional food and family business. CROSS Community Outreach Program was created for Formal Traditional Food Hawker in Surabaya. The Community Outreach was produced by Marketing Program, Marketing Students' Association and Architecture Students' Association of Petra Christian University. The Community Outreach process produced Marketing Strategy for the 20 food hawkers in Siwalankerto Food Center. The results included the new brand, new logo, business card, flyer, and social media.

Visual observation and interview were conducted in Siwalankerto Food Center to collect business problems, and potentials of the food sellers. The data was analysed to produce the integrated solutions (marketing \& architectural design) for improving the family businesses in traditional food in particular in Siwalankerto. In the design process, a discussion was conducted again with the food hawker in order to get feedback and evaluation for the integrated marketing and architectural design strategy.

The Dinas Koperasi dan UMKM Surabaya (Cooperative and Middle-Small-Micro Businesses Section of Surabaya Municipality) as well as the Food Hawkers Association of Siwalankerto accepted the program contributions and would continue the program in the following year.

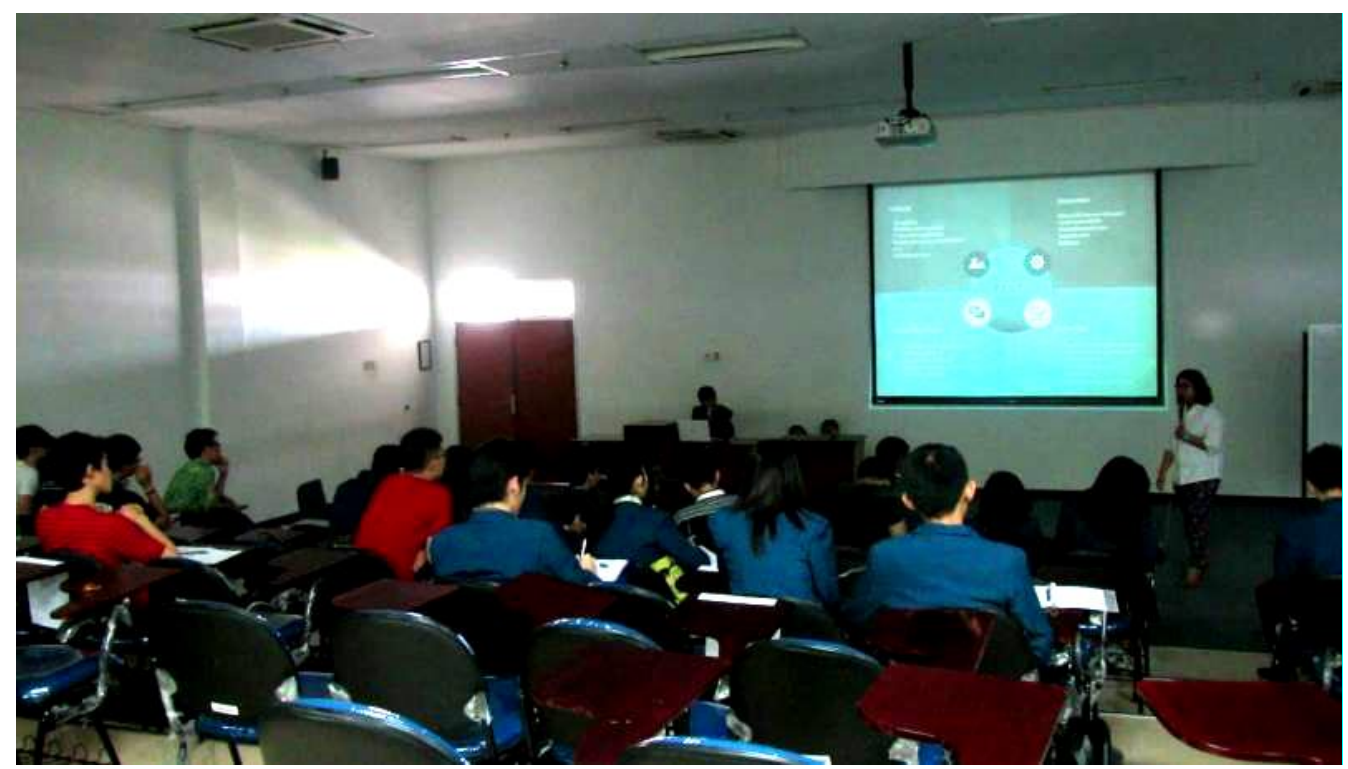

Fig. 1. CROSS Community Outreach - Marketing and Design Workshop 


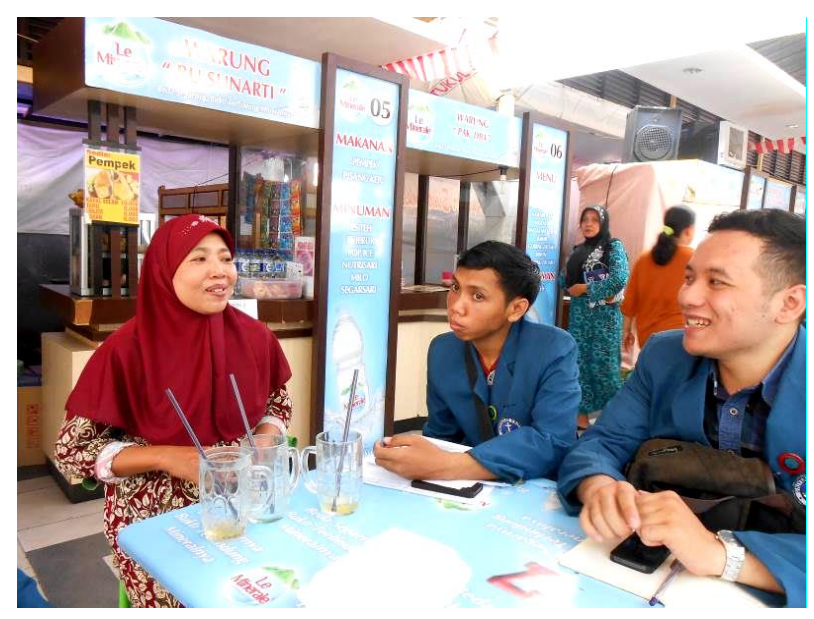

Fig. 2. CROSS Community Outreach - Interview with Food Hawker

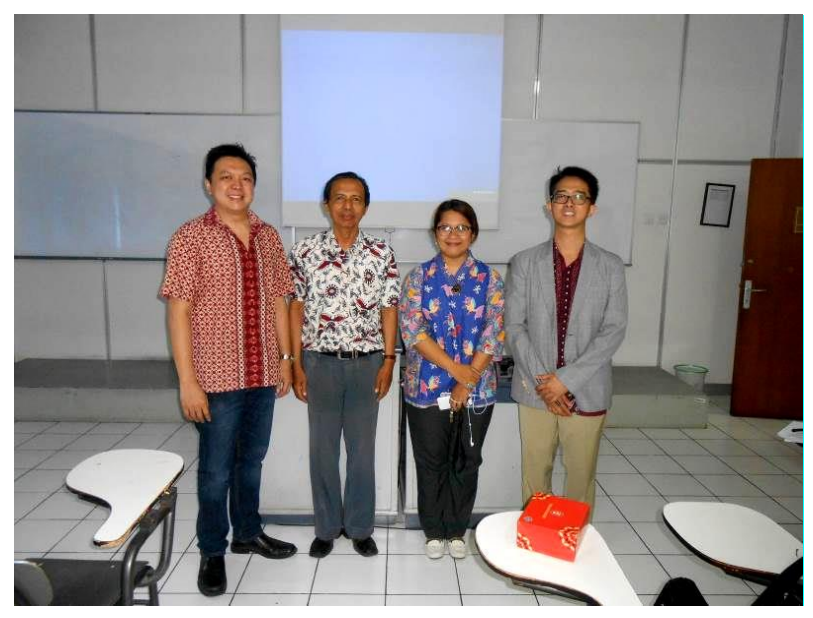

Fig. 3. CROSS Community Outreach - Mentoring

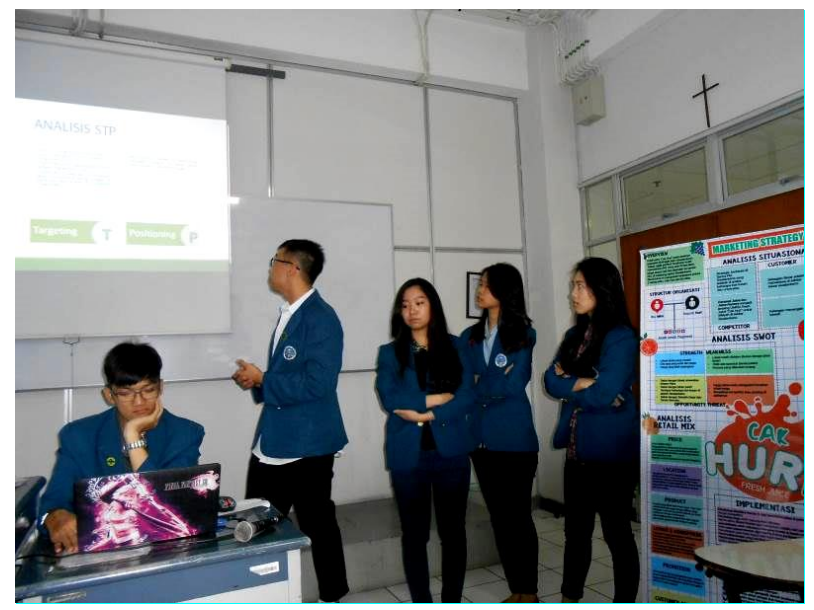

Fig. 4. CROSS Community Outreach - Presentation 


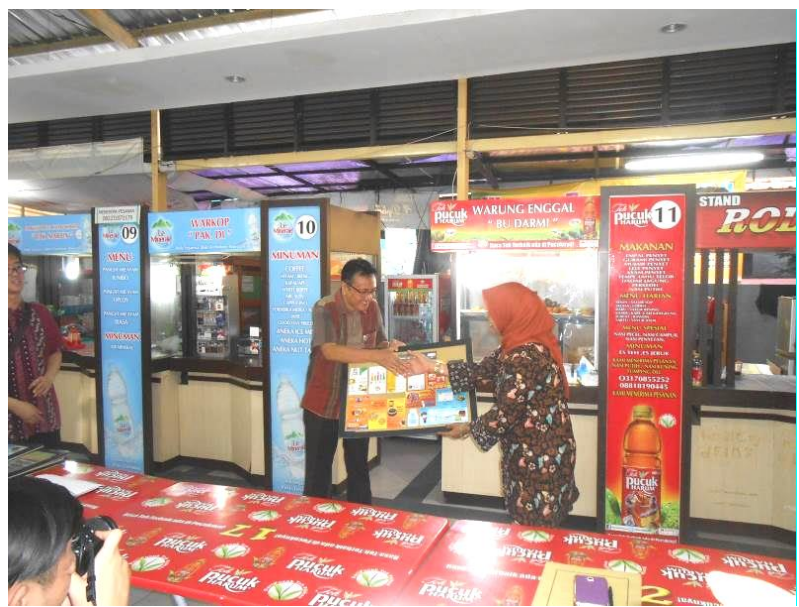

Fig. 5. CROSS Community Outreach - Closing Ceremony, Handover of results of CROSS from Marketing Program of Petra Christian University to the Dinas Koperasi dan UMKM Surabaya (Cooperative and Middle-Small-Micro Businesses Section of Surabaya Municipality).

The imaginary location of new food hawker centre was designated nearby the Petra University. The site was selected because of its strategic location and also as the vacant land. Therefore, site analysis was conducted to produce affordable solutions.

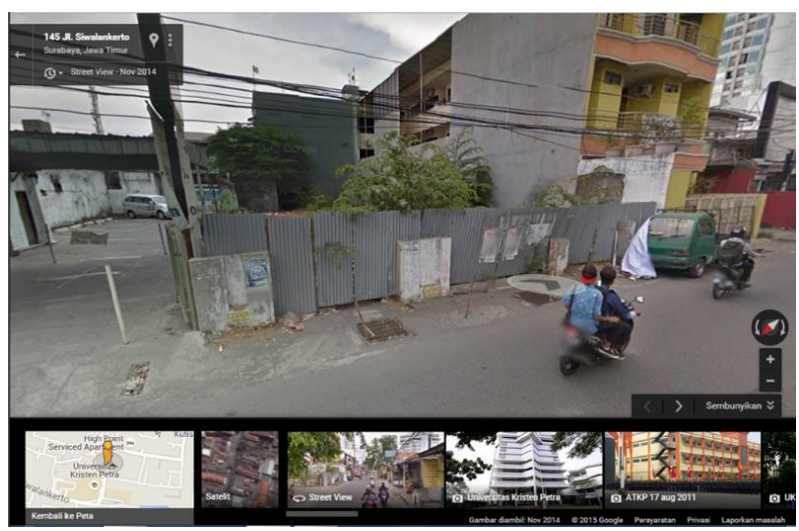

Fig. 6. Site of Proposed Food Hawker Center

\section{Results and discussion:}

The interviews with the food hawker revealed the lack of personal business identity. All counter on the hawker center were designed with similar colour, and without personal identity. They were found waiting for buyer to the hawker center and choosing the food. Also, there was a gap of business earnings between the stalls located in the front and back of the center.

An integrated marketing and architectural design strategy was proposed for catering the need of Siwalankerto food hawker. The food hawkers of Siwalankerto were found dependant to the undergraduate students and workers of Petra Christian University. Therefore, a new marketing strategy was proposed for them, including new brand design, new logo, business card, flyer, and social media. The marketing assistance was also conducted with distribution of the marketing tools as well as social media marketing in 1week time in February. With this strategy, they will have 
their own business identity that can attract their buyer. New customer will be attract to the hawker center as well as loyal customer. Also, they can develop online based shopping.
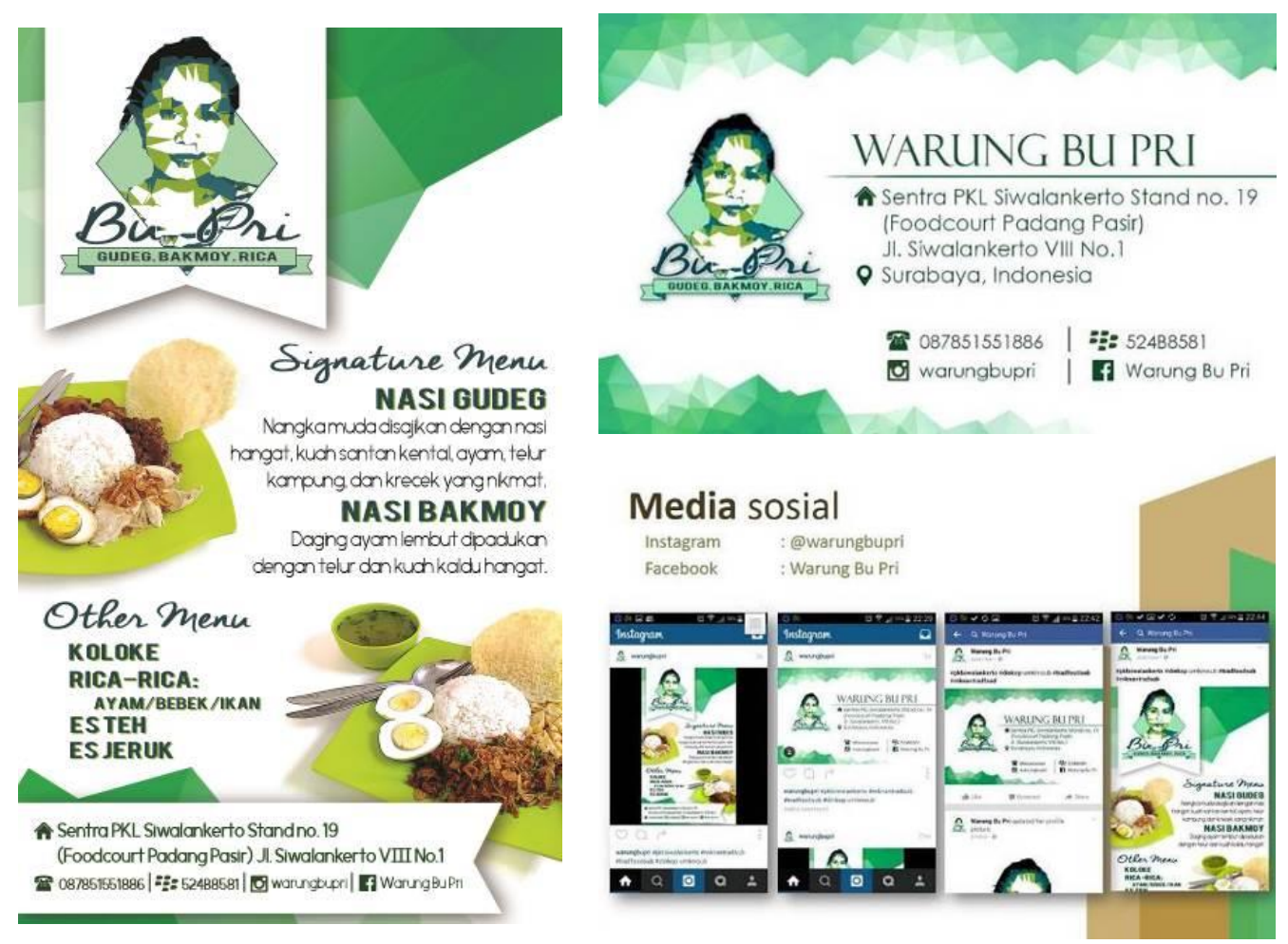

Fig. 7. The Marketing Tools of Siwalankerto Food Hawker and Food Centre - (a) Flyer, (b) Name Card, (c) Social Media (Source: Author)

The design of proposed food hawker was designed with interesting concept. The food hawker was designed with dynamic roof form as well as emphasis of the building entrance. The building entrance was designed with three advertisement boards for promoting the Food Hawker Centre. The food seller stalls were designed facing culinary parks in the north and south to facilitate visitor from both directions. Five food stalls of Siwalankerto were catered with total areas of 100 square meter. The food stalls were equipped with 4 square meter of kitchen areas and 5 square meter of indoor eating area. Every stall would be provided with neon sign board and menu board to emphasize its identity. The terms of references were selected to focus students to produce integrated marketing and architectural design strategy. Besides that, parking for 3 cars and 5 motorcycles were provided.

At the backyard, a mini playground for children was provided. The playground could cater the family with children coming from surrounding residential or kampung in Siwalankerto. The playground also were provided to attract customers to buy food in the stalls located in the back of the site. All these efforts were proposed to improve the positive image of the Family Business in this Food Hawker Centre. 


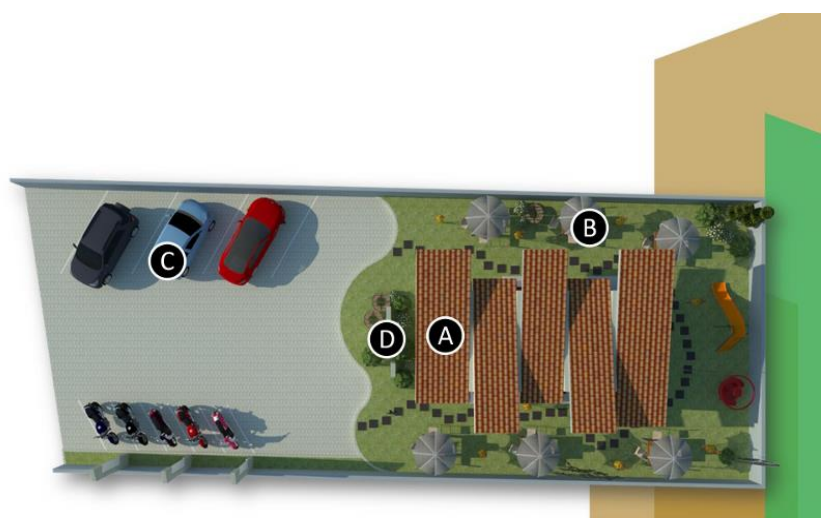

Fig. 8. Site Plan of the Hawker Centre Design, [Legend: A. Food Hawker Centre, B. Culinary Parks, C. Parking Area, D., Advertisement for the Hawker Centre] (Source: Author)

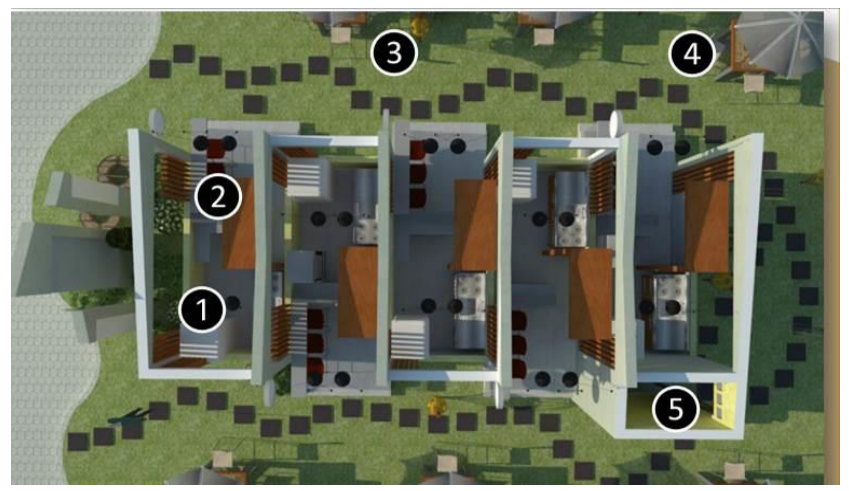

Fig. 9. The Plan of the Hawker Centre Design [Legend: 1. Kitchen, 2. Indoor Eating Area, 3. Outdoor Eating Area, 4.Playgoround, 5. Toilet] (Source: Author)

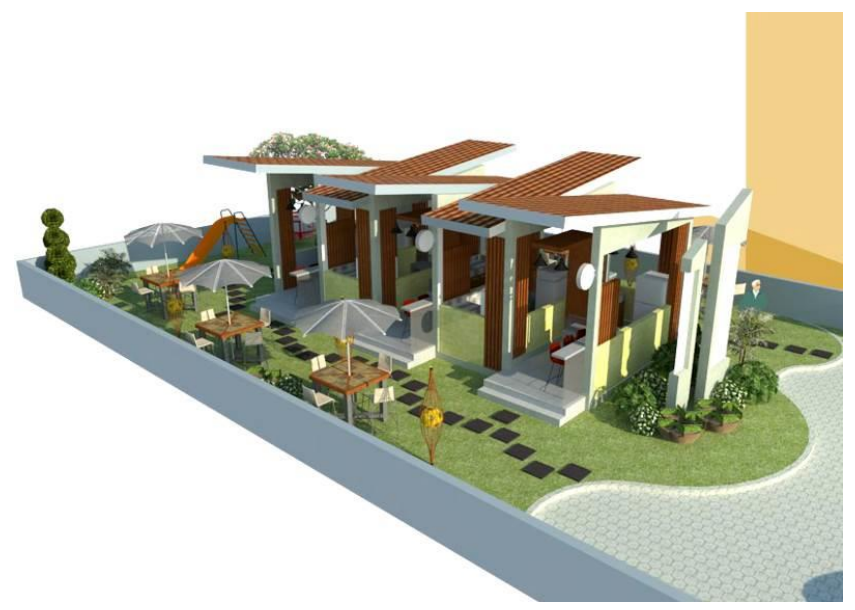

Fig. 10. The Perspectives of the Hawker Centre Design 


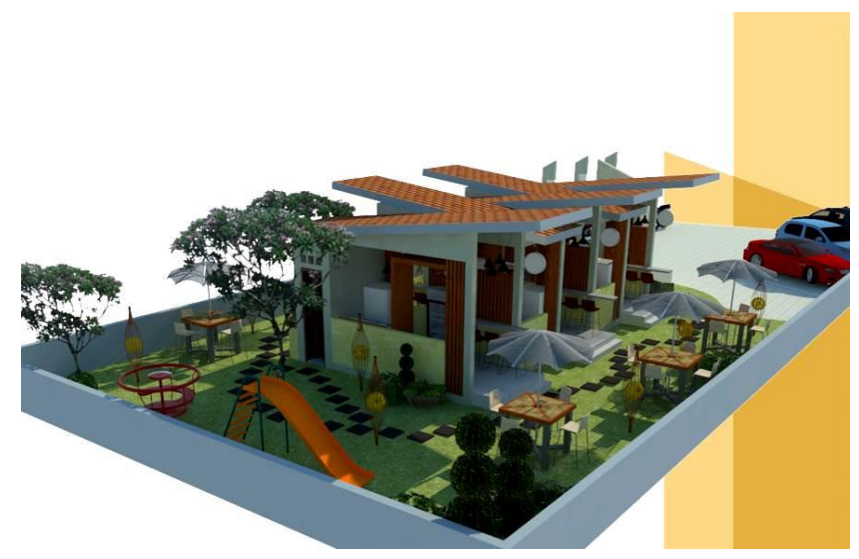

Fig. 11. The Perspectives of the Hawker Centre Design

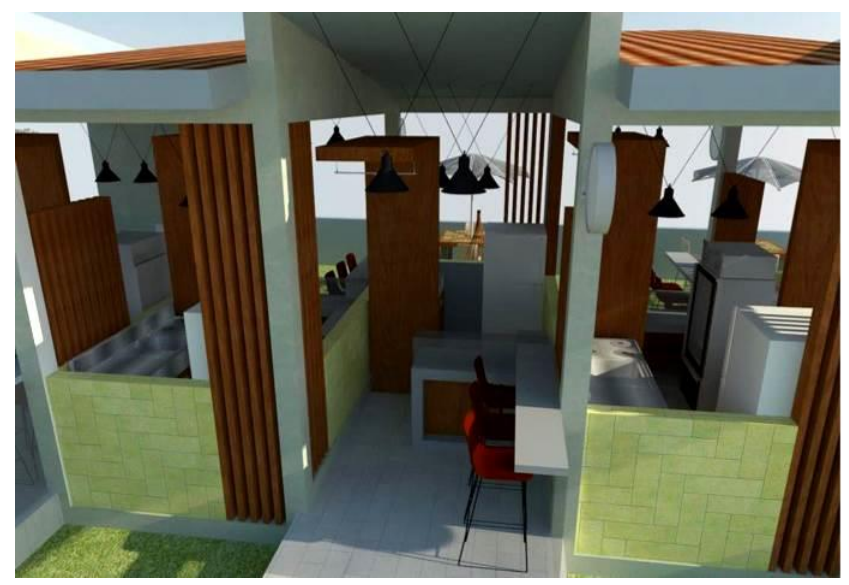

Fig. 12. The Perspectives of the Hawker Centre Design

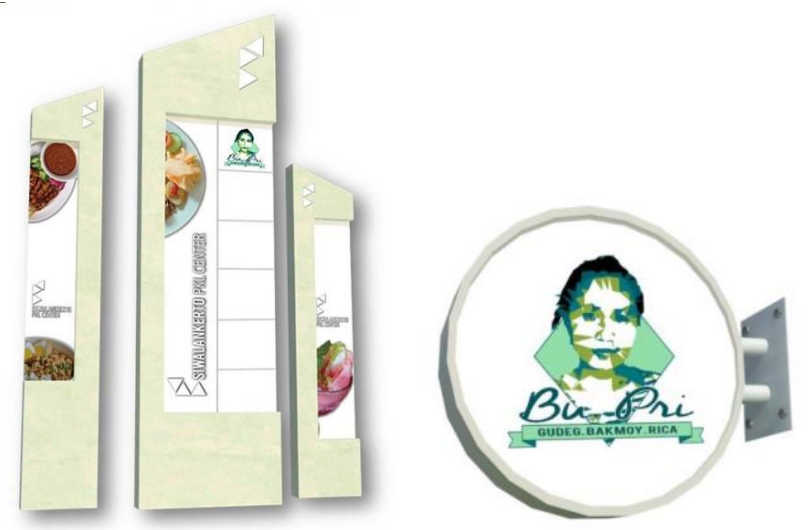

Fig. 13. Figure (a) The Advertisement Boards of the Hawker Centre Design , (b) The neon sign boards 


\section{Conclusions}

The integrated marketing and architectural design was needed by the Family Business Resilience in Traditional Food Sector in Surabaya. With collaboration of The Dinas Koperasi dan UMKM Surabaya (Cooperative and Middle-Small-Micro Businesses Section of Surabaya Municipality) and Food Hawkers Association of Siwalankerto Petra Christian University has produced the integrated solutions. Lastly, the interesting design of the food hawker played an interesting role to improve of traditional food sellers in Surabaya.

\section{Acknowledgment}

Acknowledgements are awarded to:

- United Boards of Christian Higher Education in Asia (UBCHEA)

- UNDK Indonesia

- Rector of Petra, Prof. Ir. Rolly Intan, M.A.Sc., Dr.Eng.

- Vice Rector of Petra for Academic Affairs, Prof. Dr. Ir. Djwantoro Hardjito, M.Eng.

- Head of LPPM UK Petra and Board of Director UNDK in Petra, Mrs. Dr. Juliana Anggono, S.T., M.Sc.

- Dean of Faculty of Economy, Mrs. Lim Pei Fun, SE. M.Com.

- Dinas Koperasi dan UMKM Surabaya (Cooperative and Middle-Small-Micro Businesses Section of Surabaya Municipality),

- Family Businesses in Traditional Food Sector Surabaya

- Platform Ayorek! (Creative Industries and Communities Network) - Anitha Silvia,

- Paguyuban Warga Stren Kali Surabaya (Surabaya Riverside Village Residents Association) - Gatot Subroto,

- Surabaya Punya Cerita (Stories of Surabaya) - Dhahana Adi M.I.Kom.,

- Surabaya Tempo Dulu (Old Time Surabaya) - Dukut Imam Widodo,

- Rachmad Priyandoko (CAKMAD, Illustrator and Digital Sketch Artist),

- Antonio Carlos (Surabaya Food Expert).

\section{References}

Ariffin, H. F., Bibon, M. F., \& Abdullah, R. P. S. R. (2012). Restaurant's Atmospheric Elements: What the Customer Wants. Procedia - Social and Behavioral Sciences, 38, 380-387. https://doi.org/10.1016/j.sbspro.2012.03.360

Kotler, P. (1973). Atmospherics as a Marketing Tool. Journal of Retailing, 49(4), 48-64.

Nurlaela, L., Ismawati, R., \& Sumarno. (2008). Pendokumentasian Makanan Tradisional Jawa Timur. Surabaya.

Utami, R. M., \& Lantu, D. C. (2014). Development Competitiveness Model for Small-Medium Enterprises among the Creative Industry in Bandung. Procedia - Social and Behavioral Sciences, 115, 305-323. https://doi.org/10.1016/j.sbspro.2014.02.438

Voon, B. H. (2012). Role of Service Environment for Restaurants: The Youth Customers' Perspective. Procedia - Social and Behavioral Sciences, 38, 388-395. https://doi.org/10.1016/j.sbspro.2012.03.361

Widodo, D. I. (2011). Monggo Dipun Badhog. Dukut Publishing. 